\title{
Endorser Laki-Laki Produk Kosmetik Perempuan Dan Pengaruhnya Terhadap Sikap Khalayak
}

\author{
Asprilla Riza \\ Departemen Ilmu Komunikasi, Universitas Gadjah Mada, Yogyakarta, Indonesia. \\ Email: asprilla.riza.d@mail.ugm.ac.id \\ Pulung S. Perbawani \\ Departemen Ilmu Komunikasi, Universitas Gadjah Mada, Yogyakarta, Indonesia. \\ Email: psperbawani@ugm.ac.id \\ (corresponding author)
}

\begin{abstract}
Article Info
Article History

Received 11 Dec 2020

Revised 3 Mar 2021

Accepted 9 Apr 2021
\end{abstract}

\begin{abstract}
The case of male endorser of female cosmetics product is relatively novel within the practice of marketing in Indonesia. Male and cosmetics; two concepts that are contradictory but mutually corelate. Men are understood as strong figure, masculine, and far from the association to beauty. On the other hand, cosmetics are inherently tied to the beauty itself. It becomes interesting when these two concepts are paired together within the same context of social media endorsement. This article is reporting an attempt to investigate the causative relationship between the practice of endorsement of cosmetics product by male celebrities, and how it affects the audiences' attitude. The data used in this article is gathered through an online survey on 400 respondents. Although the notion of male and cosmetics are mutually foreign, male endorsers were seen as able to influence the attitude of the audience when looking at cosmetic endorsement, toward positive tendency. However, considering the fact that most of the male endorsers of cosmetics product have effiminate appearance, it is still safe to assume that the positive statistical value did not represents similar opinion regarding men in general and cosmetics product
\end{abstract}

Keywords: endorsement, brand endorser, men, cosmetics, audience attitude

\begin{abstract}
Abstrak: Laki-laki sebagai endorser produk kosmetik wanita adalah praktik yang relatif baru dalam dunia pemasaran di Indonesia. Pria dan kosmetik-dua konsep ini saling kontradiktif tetapi berhubungan. Pria dipahami sebagai sosok yang maskulin, dan jauh dari konsep kecantikan. Di sisi lain, kosmetik secara inheren terikat dengan kecantikan itu sendiri sehingga menarik jika kedua konsep ini dipasangkan bersama dalam konteks endorsement di media sosial. Artikel ini merupakan upaya untuk menyelidiki hubungan kausatif antara praktik endorsement produk kosmetik oleh selebriti pria, dan bagaimana pengaruhnya terhadap sikap khalayak yang dilihat berdasarkan pada social influence theory. Penelitian ini menggunakan lokus pengguna media dan data dikumpulkan melalui survei terhadap 400 responden pengguna media sosial Instagram yang ada di Indonesia. Meskipun pengertian pria dan kosmetik sama-sama asing, tapi endorser pria dinilai mampu mempengaruhi sikap penonton saat
\end{abstract}


melihat kosmetik endorsement menuju kecenderungan positif. Namun, mengingat sebagian besar pria endorser produk kosmetik memiliki penampilan yang pada sampai titik tertentu dapat dikarakterisasikan sebagai feminin, maka masih dapat diasumsikan bahwa nilai statistik positif tersebut tidak mencerminkan pendapat yang sama mengenai pria pada umumnya dan produk kosmetik..

Kata kunci: brand endorser, laki-laki, kosmetik, sikap khalayak, komunikasi pemasaran

\section{PENDAHULUAN}

Produk kosmetik hampir selalu diasosiasikan dengan kaum perempuan. Hal ini kemudian berakibat kepada tren komunikasi pemasaran baik di media massa maupun media sosial yang menampilkan dominasi perempuan sebagai pengguna kosmetik. Salah satu aktivitas tersebut adalah endorsement, yang merupakan bentuk komunikasi pemasaran paling sering muncul di media sosial, melalui selebriti atau vlogger perempuan sebagai endorser-nya (Pöyry et al., 2019).

Pada satu dekade terakhir, terdapat pergeseran tren di mana semakin banyak laki-laki yang menggunakan produk kosmetik. Pada 2010, secara global, terdapat $76 \%$ laki-laki mengonsumsi produk kosmetik perempuan untuk dirinya (Basyarahil, 2017). Penelitian mengenai keterlibatan laki-laki dengan produk kosmetik perempuan pernah dilakukan sebelumnya oleh Putranto (2015). Penelitian tersebut menyoroti tentang maskulinitas laki-laki pengguna kosmetik perempuan di mata laki-laki. Keterlibatan laki-laki dengan produk kosmetik perempuan kemudian semakin berkembang tidak hanya sebagai pengguna saja, tetapi juga melakukan endorsement produk kosmetik yang dilakukan di media sosial. Bentuk keterlibatan seperti ini bukan merupakan hal yang asing di beberapa negara lain. Di Amerika Serikat, misalnya, banyak makeup artis laki-laki yang ditunjuk sebagai duta jenama kosmetik (Kumparan.com, 2018). Di Korea Selatan, praktik menggunakan boyband dan aktor laki-laki sebagai duta jenama kosmetik pun sudah lazim dilakukan (Haddad, 2019).

Di Indonesia, tren di atas merupakan hal baru yang muncul di media, khususnya media sosial. Komunikasi pemasaran produk kosmetik yang dulunya didominasi perempuan, kini mulai dirambah oleh para selebriti laki-laki. Posisi kosmetik sendiri pun kini berada pada dua sisi yang berlawanan dengan mendefinisikan ulang pria yang menarik dan maskulin di saat yang bersamaan (Kumparan.com, 2019). Kosmetik yang dianggap membawa kecantikan, tapi juga digunakan oleh lakilaki yang mewakili maskulinitas. Lebih jauh lagi, laki-laki juga menjadi pengiklan untuk produk kosmetik dalam bentuk endorsement di media sosial. Hal ini menimbulkan pertanyaan terkait penerimaan publik, khususnya konsumen produk kosmetik akan praktik endorsement oleh selebriti atau influencer laki-laki ini. Masalahnya, di Indonesia, laki-laki diasosiasikan jauh dari konsep kecantikan. Ketika mereka justru menjadi pengiklan produk kecantikan, muncullah sebuah gap antara realitas yang terjadi di Indonesia dan tren secara global terutama karena penggunaan kosmetik oleh laki-laki mungkin masih dirasa tabu di beberapa wilayah (Hestianingsih, 2017). Meskipun demikian, di negara seperti Korea Selatan 
dan Thailand, hal ini merupakan hal yang wajar (Lestari, 2020).

Fenomena endorsement produk kosmetik menggunakan endorser laki-laki di media sosial berlawanan dengan persepsi tentang kosmetik yang ada selama ini di Indonesia. Selama ini, produk kosmetik lekat dengan perempuan sehingga penggunaan endorser laki-laki yang memiliki konsep bertentangan akan menimbulkan pengaruh yang berbeda terhadap sikap khalayak (Peng, 2020). Ini belum pernah diteliti sebelumnya sehingga artikel ini ingin mengetahui pengaruh endorser laki-laki pada pemasaran produk kosmetik perempuan terhadap sikap khalayak. Konsep sikap dalam hal ini merupakan sikap khalayak terkait dengan iklan produk kosmetik perempuan seperti lipstick, bedak, eyebrow, eyeliner dan lain sebagainya. Sikap merupakan konstruksi multidimensional yang dapat berubah ketika mendapatkan pengaruh atau rangsangan objek lain (Azwar, 2008). Sikap khalayak atas iklan endorsement produk kosmetik tidak hanya dipengaruhi oleh endorser laki-laki saja, namun juga faktor yang berpengaruh dalam pembentukan sikap juga berpengaruh dalam proses ini. Dalam penelitian ini, faktor pembentuk sikap seperti information, personality, socialization \& groups, prejudice, dan value (Burns \& Dobson, 1984) merupakan variabel moderasi (M).

Artikel ini membahas praktik endorsement produk kosmetik perempuan oleh endorser laki-laki, dan pengaruhnya terhadap sikap khalayak. Fokus artikel ini adalah melakukan eksplorasi pada respon khalayak atas pesan komunikasi pemasaran, saat disandingkan dengan konteks sosial dimana laki-laki identik dengan maskulinitas, sedangkan kosmetik merupakan produk yang begitu dekat dengan konsep kecantikan.
Selama ini, laki-laki selalu digambarkan sebagai sosok yang tangguh yang erat dengan keberanian, kekuatan, kekuasaan, dominasi dan hegemoni. Kimmel dalam hal ini menyatakan sebagai berikut.

\begin{abstract}
"The hegemonic definition of manhood is a man in power, a man with power, and a man of power. We equate manhood with being successful, capable, reliable, in control. The very definitions of manhood we have developed in our culture maintain the power that some men have over other men and that men have over women. Our cultural definition of masculinity is thus several stories at once. It is about the individual man's quest to accumulate those cultural symbols that denote manhood, signs that he has in fact achieved it" (Cheng, 1999: 300).
\end{abstract}

Konsep yang dikemukakan oleh Kimmel di atas telah mengalami pergeseran yang ditandai dengan munculnya pasar baru dalam dunia kosmetik yang menargetkan laki-laki sebagai konsumennya. Dalam hal ini, lakilaki sebagai endorser kosmetik juga muncul untuk mengiklankan produk kosmetik secara umum, baik kosmetik untuk pria maupun untuk wanita. Pasar kosmetik laki-laki ini kemudian erat kaitannya dengan konsep metroseksual, di mana laki-laki peduli dengan dan rela melakukan berbagai hal agar dirinya terlihat semakin sempurna. Simpson (2002), orang pertama yang mempopulerkan istilah ini menyatakan pria metroseksual sebagai lelaki jenis baru yang memiliki minat lebih kepada citra diri yang diaktualisasikan melalui konsumsi, hingga mereka menjadi "spesies" kecintaan para pengiklan.

Meskipun banyak produk kosmetik yang dikhususkan untuk laki-laki, tak 
sedikit para laki-laki yang menggunakan produk kosmetik perempuan untuk mendukung penampilannya. Di sisi lain, meskipun wanita masih mendominasi penggunaan kosmetik, tetapi laki-laki juga memiliki angka yang tak kalah tinggi. Pada 2015, terjadi peningkatan penjualan untuk produk grooming laki-laki mencapai 300\% (Fury, 2016). Artinya, saat ini, pria juga menggunakan kosmetik hampir sama dengan jumlah perempuan. Namun pada akhirnya, media di Indonesia tidak cukup merepresentasikan keterlibatan laki-laki dengan kosmetik perempuan dalam konteks pengguna. Sejauh ini, asosiasi yang muncul antara laki-laki dan kosmetik hanya ditampilkan dalam media sebagai penunjang dari endorser utama. Kimmel (2005: 30-31) juga menjelaskan empat aturan yang memperkokoh sifat maskulinitas seorang laki-laki, yaitu jauh dari femininitas, diukur dari kesuksesan, rasionalitas, dan keberanian.

Periklanan merupakan salah satu bauran dalam komunikasi pemasaran yang dapat menarik perhatian khalayak luas karena karakteristiknya. Kotler \& Armstrong (2004) menyatakan iklan sebagai "any paid form of non personal presentation and promotion of ideas, good, and services trough mass media such as newspaper, magazines, television, or radio by an identified sponsor". Wells et al (2006) menambahkan maksud iklan itu sendiri yaitu untuk membujuk konsumen. Salah satu elemen penting dari iklan adalah sumbernya. Endorser merupakan sumber iklan yang menjadi sorotan dalam artikel ini.

Endorser adalah seorang pembicara yang mengantarkan sebuah pesan dan memeragakan sebuah produk atau jasa (Belch \& Belch, 2004). Endorser juga diartikan sebagai orang yang dipilih mewakili citra sebuah produk (product image). Pesan yang disampaikan oleh sumber yang menarik atau populer dapat mencapai perhatian yang tinggi dan diingat. Itulah mengapa pengiklan sering menggunakan endorsement sebagai spokepeople (Kotler \& Keller, 2012). Terdapat dua jenis endorser yang kerap muncul dalam iklan yaitu Celebrity endorser dan typical person endorser. Celebrity endorser adalah sosok endorser yang merupakan selebritis, artis, aktor, tokoh terkenal yang kerap muncul dalam media (Shimp \& Andrews, 2013). Celebrity endorser lebih mampu mempengaruhi khalayak, karena seorang selebriti telah memiliki khalayaknya sendiri sebelum ia mengiklanan produk. Endorser kosmetik yang menjadi fokus dalam penelitian ini adalah Jovi Adhiguna (@joviadhiguna), Glenn Alinskie (@glennalinskie), Kadir Bachmid (@d_kadoor), Ivan Gunawan (@ivan_gunawan) dan Millen Cyrus.

Terdapat tiga atribut utama yang menentukan besarnya pengaruh endorser terhadap khalayak, yakni source credibility, source atracttiveness, dan source power (Shimp \& Andrews, 2013). Atribut pertama, kredibilitas. Kredibilitas adalah tingkatan di mana konsumen melihat suatu sumber (endorser) memiliki pengetahuan, keahlian atau pengalaman yang relevan. Kredibilitas memiliki dua dimensi penting, yaitu expertise dan trustworthiness. Atribut kedua yaitu attractiveness atau daya tarik. Ini mengacu pada tampilan diri yang dianggap menarik untuk dilihat. Endorser yang dinilai menarik dianggap lebih mampu merefleksikan produk yang diiklankan secara lebih baik dari pada orang dengan daya tarik rata-rata (Mowen et al., 2002). Daya tarik memiliki tiga dimensi penting, yaitu similarity, familiarity, dan liking. Atribut terakhir, yaitu power. Ini merupakan karisma yang dipancarkan oleh endorser untuk dapat mempengaruhi konsumen sehingga konsumen sasaran terpengaruh untuk memakai produk. 
Power didefiniskan sebagai kemampuan endorser untuk memengaruhi khalayaknya.

Penggunaan endorser di media sosial menjadi begitu populer karena endorser dianggap memiliki pengaruh yang kuat untuk mengubah sikap khalayak. Hal ini dipegaruhi oleh popularitas media sosial itu sendiri, yang oleh Putra \& Febrina (2019), dikatakan sebagai sebuah revolusi. Media sosial sendiri didefinisikan sebagai "a mass self-communication media that allows all users to get information and disseminate information to the public quickly and with unlimited reach" (Arisanty et al., 2020: 266). Dalam kasus Instagram, dikatakan bahwa Instagram yang fitur-fiturnya memfokuskan aplikasi foto, video, dan telah menyita banyak perhatian pengguna daring. Instagram memungkinkan penggunanya mengambil foto, menerapkan filter digital, dan membagikannya ke berbagai layanan jejaring sosial, termasuk milik Instagram sendiri (Putra \& Febrina, 2019).

Salah satu aspek yang paling mudah dalam mengubah sikap seseorang adalah pengaruh dari orang lain (Burnkrant and Cousineau, 1975 dalam Wen, Tan, \& Chang, 2009). Untuk melihat tingkat pengaruh yang diterima khalayak, Deutsch \& Gerard (1955) mengemukakan Social Influence Theory atau Teori Pengaruh Sosial. Pengaruh yang diterima individu terbagi dalam dua tipe, yakni informational influence theory yang terjadi ketika khalayak menggunakan sumber atau source, dalam hal ini endorser, sebagai poin referensi atau sumber informasi utama mengenai produk yang diiklankan. Normative influence theory merujuk pada asumsi individu untuk menyesuaikan sikapnya dengan nilai-nilai yang dibawa oleh sumber (Wen et al., 2009).

Sikap adalah kecenderungan untuk memberikan tanggapan positif atau negatif terhadap sebuah objek atau fenomena (Ajzen, 2005). Sama seperti kepribadian, sikap merupakan hipotesis yang dapat diakses dan disimpulkan dari tanggapan yang dapat diukur. Lebih lanjut, Ajzen menawarkan pemahaman sikap sebagai multidimensional construct yang terdiri dari kognitif, afektif, dan konatif (2005: 20). Komponen kognitif merupakan representasi apa yang dipercayai oleh individu pemilik sikap. Ajzen menjelaskan bahwa komponen kognitif berisi persepsi, kepercayaan, dan stereotip yang dimiliki individu mengenai sesuatu (Ajzen, 2005). Komponen afektif merupakan perasaan yang menyangkut aspek emosional. Menurut Azwar (2008), aspek emosional inilah yang biasanya berakar paling dalam sebagai komponen sikap dan merupakan aspek yang paling bertahan terhadap pengaruh-pengaruh yang akan merubah sikap seseorang. Konatif merupakan komponen yang berkaitan dengan kecenderungan manusia untuk berperilaku. Jorgensen \& Stedman (2001) menyatakan komponen konatif terdiri dari behavioral intentions dan behavioral commitments.

Sikap bukanlah objek yang inheren dalam diri manusia, melainkan bangunan yang dihasilkan dari akumulasi dan pembelajaran. Burns dan Dobson mendifinisikan attitude formation atau pembentukan sikap terdiri dari information, personality, socialization, groups, prejudice dan value (Burns \& Dobson, 1984). Terpaan informasi, kepribadian dan sosialisasi dibutuhkan untuk melahirkan sikap individu terhadap sebuah objek. Selain itu, sikap juga bisa terbentuk sebagai hasil proses imitasi terhadap orang-orang di sekitar yang dianggap penting (Burns \& Dobson, 1984) sehingga kelompok dimana individu tersebut berada dapat mempengaruhi sikapnya. Prejudice atau prasangka berkaitan dengan aspek emosional. 
Prasangka muncul ketika individu melihat suatu objek dan menciptakan prediksi berdasarkan emosi, yang kemudian akan memberikan pengaruh pada sikap individu. Value atau nilai didefinisikan oleh Symmons-Symonolewicz et al (1960: 20) sebagai "the objective cultural elements of social life". Nilai merupakan elemen dari kebudayaan di mana seorang individu berkembang.

Sikap khalayak dianggap sebagai suatu hal yang dipengaruhi oleh atribut endorser dan dimoderasi oleh pembentukan sikap. Atribut endorser dan pembentukan sikap kemudian secara bersama-sama memengaruhi sikap khalayak atas iklan produk kosmetik. Penggunaan endorser laki-laki dalam pemasaran produk kosmetik perempuan di Instagram merupakan fenomena baru yang mencoba mendobrak stereotip lakilaki yang selama ini berkembang, di mana laki-laki jauh dari konsep kecantikan dan produk kosmetik sehingga hal ini menarik untuk diteliti. Lokus penelitiannya berada pada ranah penerimaan pesan, yakni khalayak yang menjadi sasaran dari kegiatan endorsement produk kosmetik. Khalayak adalah pengguna Instagram yang pernah terpapar endorsement produk kosmetik oleh endorser laki-laki.

\section{METODE}

Subjek penelitian ini adalah khalayak yang terpapar kegiatan endorsement produk kosmetik oleh endorser laki-laki di Instagram. Objek penelitian ini adalah sikap khalayak tersebut. Data dan hasil yang dijabarkan dalam artikel ini dikumpulkan dan dianalisis menggunakan survei daring. Survei daring dilakukan untuk dapat menjaring karakter responden yang memiliki diversitas. Sampel dikumpulkan dengan menggunakan teknik purposive sampling. Setelah data diperoleh melalui metode survei, data tersebut kemudian dianalisis menggunakan teknik analisis deskriptif, korelasi, dan regresi. Analisis korelasi dilakukan dengan menggunakan Pearson test. Analisis korelasi dilakukan terhadap variabel independen, variabel dependen, dan variabel moderasi.

\section{HASIL DAN PEMBAHASAN Temuan Penelitian}

Populasi dalam penelitian ini adalah khalayak dari kegiatan endorsement produk kosmetik, yakni perempuan yang terpapar kegiatan endorsement. Sampel yang digunakan dalam penelitian ini sebanyak 400 orang dari total populasi pengguna aktif Instagram yang berdomisili di Indonesia. Data dikumpulkan dengan menggunakan kuesioner yang lebih dulu diuji validitas dan reliabilitasnya. Uji validitas yang dilakukan dengan error margin 5\% menunjukkan nilai tertinggi pada 0.886 dan terendah adalah 0.399. Sehingga semua item atau pertanyaan yang digunakan dalam penelitian ini valid, dan dapat digunakan sebagai alat penelitian. Uji reliabilitas yang dilakukan mendapatkan hasil 0.970 yang berarti telah melampaui nilai syarat cronbach alpha, yaitu melebihi o.6 sehingga alat yang digunakan memiliki realibilitas yang tinggi.

Penelitian ini akan menguji hipotesis bahwa terdapat pengaruh antara endorser laki-laki pada pemasaran produk kosmetik perempuan di Instagram terhadap sikap khalayak.

Adapun hipotesis yang digunakan dalam penelitian ini adalah sebagai berikut.

Ho: Endorser laki-laki pada pemasaran produk kosmetik perempuan di Instagram tidak memiliki pengaruh terhadap sikap khalayak. 
H1: Endorser laki-laki pada pemasaran produk kosmetik perempuan di Instagram memiliki pengaruh terhadap sikap khalayak.

Ho: Endorser laki-laki pada pemasaran produk kosmetik perempuan di Instagram dan faktor pembentuk sikap tidak memiliki pengaruh terhadap sikap khalayak.

H2: Endorser laki-laki pada pemasaran produk kosmetik perempuan di Instagram dan faktor pembentuk sikap memiliki pengaruh terhadap sikap khalayak.
Atribut endorser merupakan variabel independen $(\mathrm{X})$ atau variabel yang memengaruhi variabel lain. Sikap khalayak merupakan variabel dependen (Y) yang dipengaruhi oleh variabel independen (X) dalam hal ini, atribut endorser. Kemudian, dimunculkan faktor yang memengaruhi pembentukan sikap sebagai variabel moderating (M). Variabel $\mathrm{M}$ \& variabel $\mathrm{X}$ bersama-sama memengaruhi sikap khalayak atas iklan produk kosmetik. Hubungan antar variabel tersebut dapat secara lebih jelas dalam kerangka konsep pada Gambar 1.

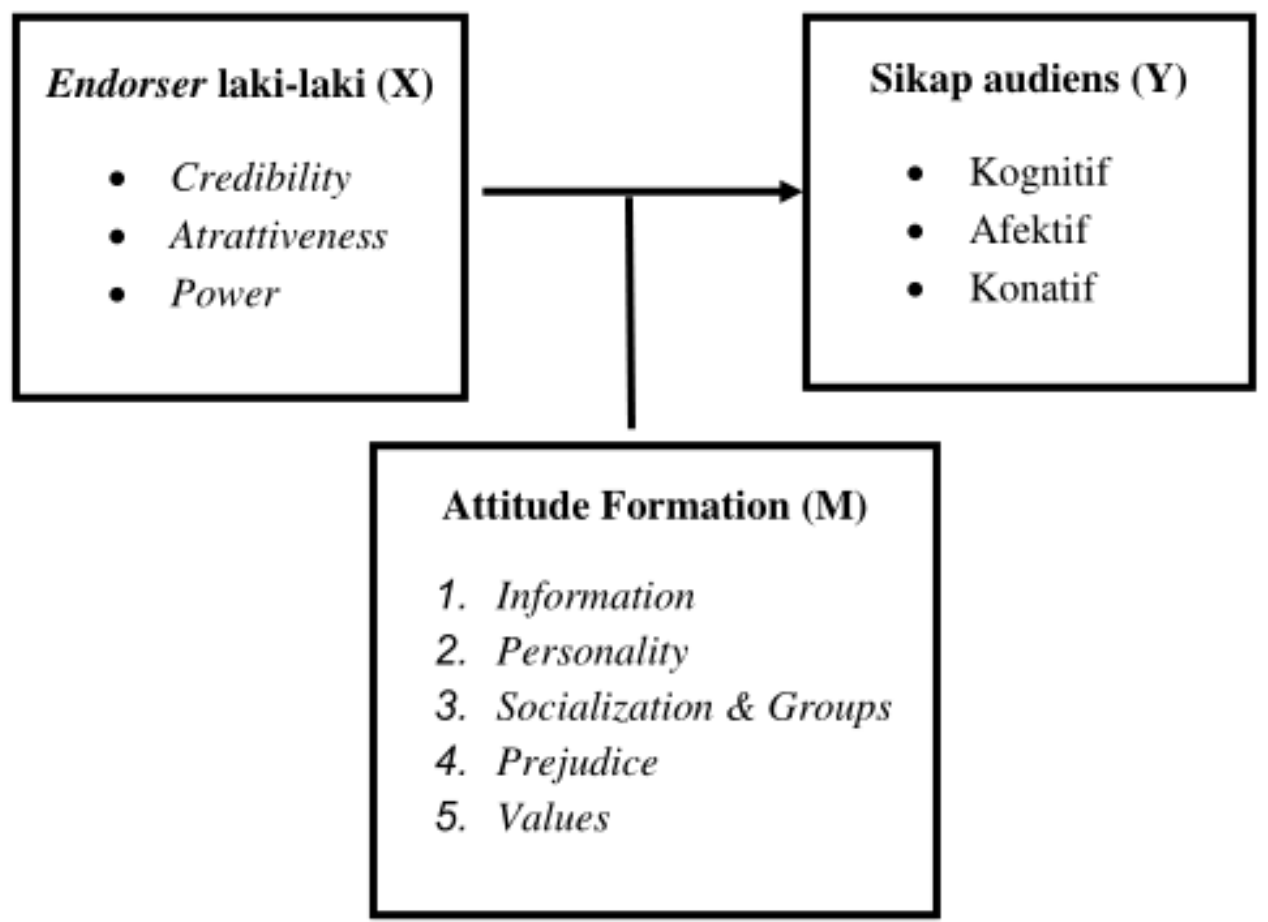

Gambar 1. Kerangka konsep penelitian

Responden dalam penelitian ini didominasi oleh perempuan sebanyak $89 \%$, sedangkan sisanya adalah $11 \%$ responden yang berjenis kelamin laki-laki. Selanjutnya, dari total 400 responden, sebanyak 123 orang atau $31 \%$ menyatakan rutin menggunakan makeup dengan $83,5 \%$ dari total responden menggunakan produk lipstik. Presentase ini sangat tinggi jika dibandingkan dengan berbagai produk kosmetik yang diiklankan oleh endorser seperti eyeliner, eyeshadow, pensil alis, maskara dan lain sebagainya. Dalam kategori skin care, sebanyak 50\% dari total responden mengaku sangat sering menggunakan skin care. Sebanyak 148 responden atau $37 \%$ menyatakan sering menjadikan Instagram untuk mencari informasi kosmetik.

Analisis korelasi dilakukan dengan menggunakan pearson test. Analisis dilakukan terhadap variabel independen, 
variabel dependen, dan variabel moderasi. Hasil analisis korelasi antara variabel independen $(\mathrm{X})$ dengan variabel dependen (Y) secara keseluruhan menunjukkan nilai pearson correlation sebesar 0.796. Hasil tersebut menunjukkan bahwa terdapat hubungan yang positif dan kuat antara variabel laki-laki endorser kosmetik dan sikap khalayak. Artinya, semakin kuat atribut endorser, semakin positif pula sikap khalayak. Selain itu, hasil analisis korelasi antara variabel moderating (M) dengan variabel dependen (Y) menunjukkan nilai pearson correlation sebesar 0.607. Hal tersebut menunjukkan bahwa terdapat hubungan yang positif dan kuat antara variabel attitude formation atau faktor pembentuk sikap dengan variabel sikap khalayak.

Selanjutnya, analisis regresi yang dilakukan pada penelitian ini dilakukan antara variabel $\mathrm{X}$ terhadap variabel $\mathrm{Y}$ dan kemudian dilanjutkan dengan pengaruh variabel $\mathrm{X}$ dan variabel $\mathrm{M}$ terhadap variabel Y. Analisis regresi yang dilakukan untuk menilai hubungan antara variabel independen atribut endorser dan variabel dependen sikap khalayak menemukan bahwa nilai signifikansinya adalah o,ooo. Hal tersebut menunjukkan koefisien regresi signifikan, atau variabel atribut endorser benar-benar berpengaruh terhadap sikap khalayak. Dengan demikian, berdasarkan hal tersebut, hipotesis penelitian ini diterima karena nilai yang muncul menunjukkan bahwa variabel atribut endorser berpengaruh terhadap variabel sikap khalayak. Selanjutnya, dilakukan analisis regresi antara variabel independen dan variabel moderasi terhadap variabel dependen. Hasil analisis regresi antara variabelvariabel tersebut menunjukkan nilai

Tabel 1. Hasil tabulasi silang antara endorser dengan Variabel Sikap khalayak (sumber:data kuesioner, diolah) signifikan yang berada pada angka o,ooo. Hal tersebut menunjukkan koefisien regresi signifikan yang berarti variabel atribut endorser bersama-sama dengan variabel faktor pembentuk sikap berpengaruh terhadap sikap khalayak.

Dalam penelitian ini, atribut endorser merupakan karakteristik yang ada selebgram laki-laki yang mengendorse produk kosmetik, sedangkan sikap khalayak ditunjukkan oleh sikap terkait iklan yang ditunjukkan oleh khalayak secara kognitif, afektif, dan konatif akibat pengaruh yang diberikan oleh sosok endorser pada iklan tersebut. Ketika variabel moderasi disertakan dalam analisis regresi, hasilnya tetap menunjukkan nilai yang memengaruhi. Dengan demikian, faktor pembentuk sikap bersamaan dengan atribut endorser mempengaruhi sikap khalayak. Faktor pembentuk sikap adalah faktor yang telah dibawa oleh khalayak, bahkan sebelum terbentuknya sikap tersebut. Ketika melihat sebuah endorsement kosmetik yang dibawakan oleh laki-laki pengguna kosmetik, faktor-faktor yang telah dipahami khalayak juga turut berperan dalam pembentukan sikap khalayak.

Selanjutnya, dilakukan pula analisis crosstab (tabulasi silang) antara endorser dengan variabel sikap khalayak. Laki-laki endorser merupakan objek penelitian dan juga objek pemantik munculnya sikap khalayak atas endorsement kosmetik. Uji tabulasi silang dilakukan kepada pertanyaan mengenai laki-laki endorser dan hubungannya dengan variabel sikap khalayak. Tabel 1 menunjukkan hasil uji tabulasi silang antara endorser dengan sikap khalayak.

\begin{tabular}{ccccc}
\hline No & Pertanyaan & Chi $^{2}$ Tabel & Chi $^{2}$ Hitung & Keterangan \\
\hline 82 & & & \\
\hline
\end{tabular}




\begin{tabular}{|c|c|c|c|c|}
\hline 1 & $\begin{array}{l}\text { Saya merasa endorsement } \\
\text { produk kosmetik yang dilakukan } \\
\text { laki-laki tampak meyakinkan }\end{array}$ & 26.296 & 43.281 & Berkorelasi \\
\hline 2 & $\begin{array}{l}\text { Saya memberikan penilaian } \\
\text { positif pada endorsement } \\
\text { kosmetik yang dibawakan oleh } \\
\text { laki-laki }\end{array}$ & 26.296 & 41.015 & Berkorelasi \\
\hline 3 & $\begin{array}{l}\text { Saya memiliki pemahaman } \\
\text { sendiri ketika melihat } \\
\text { endorsement kosmetik yang } \\
\text { dibawakan laki-laki }\end{array}$ & 26.296 & 27.226 & Berkorelasi \\
\hline 4 & $\begin{array}{l}\text { Saya menyukai endorsement } \\
\text { produk kosmetik yang } \\
\text { dibawakan laki-laki }\end{array}$ & 26.296 & 30.507 & Berkorelasi \\
\hline 5 & $\begin{array}{l}\text { Saya penasaran dengan produk } \\
\text { kosmetik yang di- endorse oleh } \\
\text { laki-laki }\end{array}$ & 26.296 & 50.029 & Berkorelasi \\
\hline 6 & $\begin{array}{l}\text { Saya berniat untuk mencari } \\
\text { informasi mengenai produk } \\
\text { kosmetik yang di- endorse oleh } \\
\text { laki-laki }\end{array}$ & 26.296 & $35 \cdot 310$ & Berkorelasi \\
\hline 7 & $\begin{array}{l}\text { Saya menjadi yakin untuk } \\
\text { memilih produk kosmetik yang } \\
\text { di- endorse laki-laki }\end{array}$ & 26.296 & 30.199 & Berkorelasi \\
\hline 8 & $\begin{array}{l}\text { Saya menjadi yakin untuk } \\
\text { mencoba produk kosmetik yang } \\
\text { di- endorse laki-laki }\end{array}$ & 26.296 & 31.399 & Berkorelasi \\
\hline
\end{tabular}

Hasil uji chi-square antara laki-laki endorser kosmetik dengan atribut sikap khalayak pada tabel di atas menunjukkan beberapa item yang saling berkorelasi. Berdasarkan pada dimensi belief: "Saya merasa endorsement produk kosmetik oleh laki-laki tampak meyakinkan”, ditunjukkan bahwa terdapat kecenderungan netral dari khalayak untuk memilih mempercayai iklan atau tidak. Hal ini berarti bahwa khalayak masih memertimbangkan apakah iklan yang ditunjukkan oleh endorser meyakinkan atau tidak. Kepercayaan khalayak terhadap endorser akan membuat khalayak lebih percaya dengan produk yang di-endorse dan yakin untuk memiih produk yang diiklankan. Lebih jauh lagi, produk yang digunakan secara langsung oleh endorser, akan menambah keyakinan khalayak bahwa produk tersebut memang bagus dan layak untuk digunakan.
Berdasarkan dimensi emotional: "Saya menyukai endorsement produk kosmetik yang dibawakan laki-laki”, hasil uji tabulasi silang menunjukkan bahwa khalayak memiliki kecenderungan untuk menyukai, tetapi lebih memilih mempertimbangkan ulang. Selain itu, ditemukan pula bahwa khalayak cenderung menyukai iklan dengan melihat sosok yang ditampilkan dalam iklan tersebut. Ketika sosok endorser tersebut menarik bagi khalayak, ia juga akan menyukai iklan yang dibawakan endorser tersebut.

Terakhir, dimensi informational: "Saya menjadi yakin untuk mencoba produk kosmetik yang di-endorse lakilaki”, hasil tabulasi silang menunjukkan bahwa endorser kurang mampu membuat khalayak yakin untuk mencoba produk yang diiklankan. Hal tersebut diperkuat 
dengan hasil analisis tabulasi silang pada sikap kognitif mempercayai iklan yang menunjukkan hasil cenderung netral. Khalayak masih perlu mempertimbangkan lagi untuk mempercayai iklan atau tidak karena masih perlu mempertimbangkan, maka mereka pun juga menjadi ragu untuk mencoba produk.

\section{Analisis Temuan}

Analisis dalam penelitian ini dilakukan dengan menggunakan analisis deskriptif, analisis korelasi, dan analisis regresi. Analisis korelasi digunakan untuk mengetahui hubungan atau asosiasi antar variabel dengan menggunakan koefisien korelasi. Analisis regresi dilakukan untuk mengetahui hubungan antara variabel hubungan linier antara variabel independen (X) dan dependen (Y) dan hubungan liniear antar variabel independen (X) bersama variabel moderating (M) dengan dependen (Y). Analisis deskriptif dalam penelitian ini menggunakan analisis mean dan crosstab untuk menggambarkan kecenderungan responden.

Penelitian ini menemukan bahwa terdapat korelasi yang kuat antara atribut endorser dan sikap khalayak. Hal ini berarti semakin kuat atribut endorser, semakin positif pula sikap khalayak. Selain itu, khalayak pula hubungan yang kuat antara variabel attitude formation dengan sikap khalayak. Ini berarti bahwa semakin kuat attitude formation, semakin positif pula sikap khalayak. Lebih lanjut, analisis regresi menemukan bahwa hipotesis dalam penelitian ini diterima yang menunjukkan bahwa variabel atribut endorser berpengaruh terhadap variabel sikap khalayak. Selain itu, ketika variabel moderasi disertakan dalam uji regresi, ditemukan bahwa variabel atribut endorser dan variabel faktor pembentuk sikap berpengaruh terhadap variabel sikap khalayak.

Sesuai dengan pendapat Shimp \& Andrews (2013) untuk menggambarkan endorser laki-laki dapat dilihat melalui tiga atribut yang dimilikinya sebagai seorang endorser, yakni credibility, attractiveness, dan power. Sebaliknya, sikap khalayak merupakan pemahaman multidimensional yang dilihat sebagai sebuah hasil akhir sikap itu sendiri. Sikap terdiri dari aspek kognitif, afektif, dan konatif (Ajzen, 2005). Pemahaman mengenai sikap tidak sebatas ditimbulkan oleh objek sikap saja, melainkan ada faktor-faktor lain yang turut berperan di baliknya. Faktor-faktor yang berpengaruh dalam pembentukan sikap terdiri dari information, personality, socialization, groups, prejudice, dan values (Burns \& Dobson, 1984). Sikap yang digali adalah sikap atas endorsement kosmetik yang dibawakan laki-laki. Oleh karena itu, faktor pembentuk sikap yang melatarbelakangi terkait dengan pemahaman laki-laki pengguna kosmetik itu sendiri. Kelima faktor tersebut secara bersama-sama membentuk sikap akhir khalayak atas endorsement kosmetik yang dibawakan laki-laki. Ketiga konsep tersebut kemudian diolah untuk mencari hubungan antara ketiganya.

Ketika dihadapkan dengan laki-laki yang meng-endorse produk kosmetik perempuan, khalayak menunjukkan sikap pada aspek kognitif yang lebih tinggi. Ini sejalan dengan penelitian yang dilakukan oleh Kurniawan et al (2019) bahwa celebrity endorser akan mendorong adanya aspek kognitif yang positif sehingga kemudian mempengaruhi sikap khalayak, sedangkan pada aspek berikutnya, yakni afektif dan konatif diketahui nilainya menurun. Khalayak yang menjadi responden penelitian ini adalah mereka pengguna kosmetik yang juga mengikuti endorser dan didominasi perempuan. Mereka memang sengaja mengakses 
Instagram untuk mencari informasi mengenai kosmetik. Ketika muncul bentuk endorsement kosmetik, mereka lebih mudah memahami hal tersebut karena memang mereka butuhkan ketika mengakses Instagram.

Terlepas dari kebutuhan khalayak tersebut, sosok endorser lebih berperan penting terhadap pemahaman khalayak. Endorser yang diikuti khalayak didominasi oleh mereka yang memang ahli dalam bidang kosmetik. Mereka juga dinilai meyakinkan ketika membawakan iklan. Ketika informasi berasal dari endorser yang dianggap kredibel, hal tersebut mampu memengaruhi proses psikologi yang disebut internalisasi, di mana kredibel menyetujui pendapat dari penyampai pesan. Ini sesuai dengan pernyataan Wang et al (2017: 11) "Information from a credible source (e.g. celebrity) can influence beliefs, opinions, attitudes and/or behavior through a process called internalization, which occurswhen receivers accept a source influence in terms of their personal attitude and value structures." Oleh karena itu, sosok endorser yang kredibel dapat membantu memahami pesan endorsement produk kosmetik yang dibawakan.

Dari hasil uji regresi, ditemukan bahwa atribut endorser memengaruhi sikap kredibel. Hasilnya juga menunjukkan nilai yang positif. Artinya, semakin kuat atribut yang dimiliki endorser, semakin positif pula sikap yang ditunjukkan khalayak. Penggunaan endorser pada iklan berperan sebagai penyampai pesan iklan untuk menarik perhatian dan memengaruhi khalayak. Begitu pula dengan yang terjadi dengan endorsement di media sosial Instagram. Endorsement sebagai sebuah iklan juga berfungsi untuk memengaruhi khalayaknya. Peran endorser di sini menjadi hal krusial karena telah diketahui melalui beberapa pengujian bahwa endorser memengaruhi khalayak, dalam hal ini sikap yang ditunjukkan.

Endorser kosmetik merupakan sosok yang memang dekat dengan kosmetik. Mereka mempedulikan penampilan, terlihat dari penampilannya di Instagram yang dinilai menarik. Mereka juga ahli dalam hal kosmetik, terlihat dari banyaknya nama-nama endorser yang memang berprofesi sebagai MUA atau beauty influencer. Keahlian merupakan salah satu pembangun kredibilitas sumber pesan. Keahlian ini berkaitan dengan kompetensi yang dirasakan pada endorser ketika memberikan klaim berdasarkan pada pengetahuan, pengalaman, atau keterampilan pendukung yang dimilikinya (Munnukka et al., 2016). Dengan keahlian yang dimiliki tersebut, khalayak lebih mudah memahami dan menerima ketika mereka membawakan sebuah iklan kosmetik. Keahlian para endorser kosmetik tersebut merupakan pendorong bagi khalayak untuk memberikan sikap yang positif. Tidak hanya itu, endorser merupakan sosok yang memiliki kharisma. Kharisma yang dimiliki endorser terkait dengan penerimaan dirinya di mata khalayak. Meskipun laki-laki yang mengendorse kosmetik masih cukup jarang di Indonesia, nyatanya mereka bisa diterima. Penerimaan inilah yang kemudian menjadikannya sejalan dengan sikap yang ditunjukkan. Artinya, semakin diterima sosok endorser, khalayak juga menunjukkan sikap yang makin positif.

Pada uji regresi dengan memasukkan variabel moderating, yaitu faktor pembentuk sikap, terlihat bahwa variabel moderating bersifat memperkuat hubungan pengaruh dari atribut endorser terhadap sikap khalayak. Faktor pembentuk sikap merupakan faktor-faktor terkait pria pengguna kosmetik. Sikap yang dihasilkan adalah sikap atas endorsement kosmetik yang dibawakan laki-laki, 
termasuk di dalamnya laki-laki pengguna kosmetik sehingga ketika khalayak sudah cukup aware dengan pria pengguna kosmetik mulai dari konsumsi informasi hingga budaya yang dianut. Ini memerkuat pengaruh endorser laki-laki. Dengan kata lain, semakin kuat atribut endorser dan semakin dekat khalayak dengan pria pengguna kosmetik, maka semakin positif pula sikap yang dihasilkan khalayak.

Untuk memperkaya hasil penelitian, dilakukan uji crosstab. Uji crosstab dilakukan untuk melihat hubungan antar pertanyaan. Uji crosstab menghubungkan variabel yang dinilai memiliki hubungan khusus dan diketahui bagaimana distribusinya. Dari hasil crosstab, diketahui bagaimana perbandingan jumlah pengguna kosmetik laki-laki dan perempuan. Kosmetik sendiri terdiri dari makeup dan skincare. Khalayak perempuan menunjukkan tingkat penggunaan makeup dan skincare yang cukup tinggi. Berbeda dengan laki-laki yang menunjukkan hanya penggunaan skincare saja yang tinggi. Hal ini kemudian bisa dikaitkan dengan budaya laki-laki pengguna kosmetik dipandang sebagai sesuatu yang kurang wajar oleh khalayak. Lingkungan sosial turut memengaruhi sikap. Lingkungan sosial khalayak cukup sering membicarakan laki-laki pengguna kosmetik. Namun, mereka masih belum menganggap hal tersebut sebagai suatu hal yang wajar. Dari hasil pengujian crosstab juga ditemukan bahwa laki-laki yang menunjukkan sikap feminin atau effeminate lebih bisa diterima khalayak untuk mengiklankan produk kosmetik. Hal ini menjadi masuk akal jika dikaitkan dengan konsep maskulinitas di Indonesia yang masih kaku. Penggunaan kosmetik takut dianggap melukai konsep maskulinitas yang melekat pada laki-laki sehingga sosok laki-laki feminin cenderung lebih berkembang dan diterima ketika mengiklankan produk kosmetik.
Dari semua hasil pengujian yang telah dilakukan, dapat disimpulkan bahwa endorser laki-laki yang membawakan iklan kosmetik perempuan mampu memengaruhi sikap yang dihasilkan khalayak. Sikap yang dihasilkan berupa pemahaman (kognitif), emosional (afektif), dan kecenderungan untuk berperilaku (konatif). Seorang endorser yang dianggap kredibel, menarik, dan berkharisma oleh khalayak akan memantik sikap yang positif pada semua aspek sikap. Namun, pengaruh endorser ini paling kuat memantik sikap kognitif khalayak saja. Di samping itu, faktor-faktor pembentuk sikap yang telah dibawa khalayak juga berpengaruh dalam membentuk sikap khalayak. Khalayak yang terbuka dengan pria pengguna kosmetik akan menghasilkan sikap yang juga positif. Namun, pengaruhnya tidak terlalu signifikan. Ini karena endorser adalah yang dilihat ketika membentuk sikap atas endorsement sehingga endorser-lah yang berpengaruh paling kuat pada sikap khalayak. Penelitian dengan perspektif semiotika yang dilakukan oleh Peng (2020) menunjukkan bahwa iklan produk kosmetik wanita oleh laki-laki menjadi mungkin karena adanya peningkatan status sosial dalam diskursus mengenai wanita dan adanya penerimaan laki-laki sebagai seks pertama. Lebih lanjut, berdasarkan penelitian Hsiao \& Li (2019), bagi konsumen wanita, endorser lawan jenis akan memberikan dampak yang positif terhadap iklan dan produk yang diiklankan.

\section{KESIMPULAN}

Penelitian ini bertujuan untuk mengetahui pengaruh endorsement kosmetik yang dibawakan oleh laki-laki terhadap sikap khalayak. Dari hasil uji pearson correlation, ditemukan bahwa terdapat korelasi positif antara kedua 
variabel utama penelitian, yaitu variabel endorser laki-laki dan sikap khalayak. Ini berarti hipotesis penelitian terbukti. Selanjutnya, ditemukan dari hasil analisis bahwa responden menunjukkan respon positif pada seluruh aspek atribut endorser. Dari data tersebut, dapat diketahui bahwa khalayak menganggap selebgram laki-laki yang meng-endorse kosmetik merupakan sosok yang kredibel, menarik, dan berkharisma. Namun, dari ketiganya, kredibilitas memiliki nilai yang paling tinggi. Ini terkait dengan latar belakang endorser yang mayoritas merupakan sosok publik figur yang memang dekat dengan dunia kosmetik.

Dari ketiga aspek sikap yang digali dalam penelitian ini, khalayak menunjukkan respon yang beragam. Sikap yang ditunjukkan khalayak cenderung positif pada aspek kognitif. Artinya, secara pemahaman, khalayak bisa menerima dan memahami endorsement kosmetik yang dibawakan oleh laki-laki. Khalayak menilai bahwa endorsement kosmetik tersebut cukup informatif menyampaikan pesan iklan. Namun, endorsement kurang mampu menyentuh khalayak secara emosional. Khalayak juga cenderung merespon negatif pada kecederungan bertindak. Artinya, endorsement kosmetik yang dibawakan laki-laki kurang memantik khalayak untuk berperilaku seperti mencari informasi mengenai produk dan mencoba produk.

Meskipun laki-laki dan kosmetik memiliki konsep yang bertentangan, tapi laki-laki endorser kosmetik mampu memengaruhi sikap khalayak ketika melihat endorsement kosmetik. Sikapnya juga menunjukkan kecenderungan positif. Laki-laki endorser yang lebih disukai memiliki tampilan yang jauh dari maskulin dan cenderung feminin. Dari sini, dapat disimpulkan bahwa masyarakat Indonesia belum sepenuhnya bisa menyandingkan antara konsep kosmetik dengan konsep maskulinitas. Di Indonesia, konsep kosmetik masih lekat dengan femininitas. Ini juga diperkuat dengan kekangan konsep maskulinitas yang masih kaku sehingga sulit menyandingkan kosmetik dengan laki-laki.

Penelitian ini mampu menjelaskan peran endorser laki-laki dalam endorsement kosmetik. Hasil penelitian menunjukkan adanya perubahan persepsi khalayak bahwa kosmetik tidak lagi merupakan hal yang tabu bagi laki-laki. Ini berarti bahwa Indonesia cepat atau lambat terbawa tren endorsement kosmetik oleh laki-laki seperti yang sudah terjadi di Korea, Jepang, Thailand dan Amerika. Ini merupakan peluang yang dapat dimanfaatkan oleh pelaku dunia periklanan. Namun, perlu juga diperhatikan bahwa sebagian besar lakilaki yang meng-endorse kosmetik perempuan yang disebutkan dalam penelitian ini memiliki kecenderungan penampilan yang feminin. Jadi, meskipun asosiasi kosmetik dengan gender sudah berubah, tetapi asosiasi dengan feminitas masih bertahan.

Penelitian ini masih memiliki keterbatasan metode karena tidak membandingkan posisi endorser laki-laki dan perempuan untuk produk kosmetik perempuan di mata khalayak. Selain itu, banyak konsep yang disebutkan dalam penelitian ini yang masih bisa dieksplorasi, seperti maskulinitas, konten endorsement, hingga budaya laki-laki pengguna kosmetik yang bisa dikaitkan dengan isu dan metode yang sesuai. Oleh karena itu, perlu dilakukan penelitian yang mengeksplorasi konsep-konsep tersebut. 


\section{DAFTAR PUSTAKA}

Ajzen, I. (2005). Attitudes, personality, and behavior. Open University Press. https://books.google.co.id/books?id =dmJ9EGEyoZYC

Arisanty, M., Wiradharma, G., \& Fiani, I. (2020). Optimizing social media platforms as information disemination media. Jurnal ASPIKOM , 5(2), 266. https://doi.org/10.24329/aspikom.v 5i2.700

Azwar, S. (2008). Sikap manusia teori dan pengukuran (kedua). Pustaka Pelajar.

Basyarahil, M. A. (2017). Analisis faktorfaktor yang mempengaruhi minat beli kosmetik pria pada mahasiswa fakultas ekonomi dan bisnis Universitas Brawiajaya (Studi kasus pada mahasiwa S1 prodi ekonomi islam fakultas ekonomi dan bisnis Universitas Brawijaya). Jurnal Ilmiah Mahasiswa FEB, 5(2), 1-12. http://repository.ub.ac.id/id/eprint/ 2740

Belch, G., \& Belch, M. (2004). Advertising and promotion: An integrated marketing communications perspective. The McGraw Hill. https://www.mheducation.com/high ered/product/1260259315.accessibili ty.html

Burns, R. B., \& Dobson, C. B. (1984). Introductory psychology. Springer Netherlands. https://doi.org/10.1007/978-94-0116279-1

Cheng, C. (1999). Marginalised masculinities and hegemonic masculinity: An introduction. Journal of Men's Studies, 7(3), 295310.

Deutsch, M., \& Gerard, H. B. (1955). A study of normative and informational social influences upon individual judgment. The Journal of Abnormal and Social Psychology, 51(3), 629636.

https://doi.org/10.1037/hoo46408

Fury, A. (2016). Men's grooming is now a multi-billion pound worldwide industry. Independent.

https://www.independent.co.uk/lifestyle/fashion/features/mensgrooming-is-now-a-multi-billionpound-worldwide-industrya6813196.html

Haddad, H. (2019). Men in makeup: KPop male celebrities are changing the perception of male beauty. Eonline.Com.

https://www.eonline.com/ap/news/1 076719/men-in-makeup-koreanmale-celebrities-are-changing-theperception-of-male-beauty

Hestianingsih. (2017). Tren pria jadi model produk kosmetik, bentuk kebebasan berekspresi? Wolipop Detik.Com.

https://wolipop.detik.com/makeupand-skincare/d-3388795/tren-priajadi-model-produk-kosmetik-bentukkebebasan-berekspresi

Hsiao, Y.-C., \& Li, X.-L. (2019). Research on whether or not the opposite-sex endorsement of intimate products affects the advertising effectiveness. Journal of Economics, Business and Management, $7(4), 170-173$. https://doi.org/10.18178/joebm.2019 $\cdot 7 \cdot 4.601$

Jorgensen, B. S., \& Stedman, R. C. (2001). Sense of place as an attitude: Lakeshore owners attitudes toward their properties. Journal of Environmental Psychology, 21(3), 233-248. https://doi.org/10.1006/jevp.2001.o 226 
Kimmel, M. (2005). What about the boys? In Critical Social Issues in American Education (3rd ed.). Lawrence Erlbaum Associates Inc.

Kotler, P., \& Armstrong, G. (2004). Principles of marketing. Pearson Prentice Hall.

Kotler, P., \& Keller, K. L. (2012). Marketing management (14th ed.). Prentice Hall.

Kumparan.com. (2018). Laki-laki dandan dan geliat industri kosmetik pria. Kumparan. https://kumparan.com/kumparansty le/laki-laki-dandan-dan-geliatindustri-kosmetik-pria/full

Kumparan.com. (2019). Laki-laki dan makeup, antara tren dan kebutuhan. Kumparan.

https://kumparan.com/kumparansty le/laki-laki-dan-makeup-antara-trendan-kebutuhan1548851137223181511/full

Kurniawan, Y., Sidik, A., \& Goenawan, F. (2019). Sikap pemirsa televisi terhadap penggunaan celebrity endorser Agnez Mo dalam iklan sampo clear "Sikat Habis Ketombe." Jurnal E-Komunikasi, 7(2). https://scholar.google.com/scholar? $\mathrm{hl}=$ en\&as_sdt $=0 \% 2 \mathrm{C} 5 \& \mathrm{q}=\mathrm{Sikap}+\mathrm{Pe}$ mirsa+Televisi+Terhadap+Pengguna an+Celebrity+Endorser+Agnez $+\mathrm{Mo}+$ Dalam+Iklan+Sampo+Clear+"Sikat+ Habis+Ketombe"\&btnG=

Lestari, V. (2020). Tidak biasa, beberapa brand kosmetik ini memilih model priajadi bintang iklannya.

Heboh.Com. https://heboh.com/tidak-biasabeberapa-brand-kosmetik-inimemilih-model-pria-jadi-bintangiklannya

Mowen, J., Michael, M., \& Yahya, D. K. (2002). Perilaku konsumen (Pertama). Erlangga. https://opac.perpusnas.go.id/Detail Opac. aspx?id=312314
Munnukka, J., Uusitalo, O., \& Toivonen, H. (2016). Credibility of a peer endorser and advertising effectiveness. Journal of Consumer Marketing, 33(3), 182-192. https://doi.org/10.1108/JCM-112014-1221

Peng, T. (2020). From semiotic perspective: Male endorsements in cosmetic advertising. International Conference on Educational Innovation and Philosophical Inquiries (ICEIPI 2O2O), 62-73.

Pöyry, E., Pelkonen, M., Naumanen, E., \& Laaksonen, S.-M. (2019). A call for authenticity: Audience responses to social media influencer endorsements in strategic communication. International Journal of Strategic Communication, 13(4), 336-351.

https://doi.org/10.1080/1553118X.2 019.1609965

Putra, A. M., \& Febrina, A. (2019). Fenomena selebgam anak: Memahami motif orang tua. Jurnal ASPIKOM, 3(6), 1093. https://doi.org/10.24329/aspikom.v 3i6.396

Putranto, A. E. (2015). Maskulinitas lakilaki pengguna kosmetik perempuan di mata laki-laki. Universitas Gadjah Mada.

Shimp, T. A., \& Andrews, J. C. (2013). Advertising, promotion, and other aspects of integrated marketing communications (9th ed.). Cengage Learning.

Simpson, M. (2002). Meet the metrosexual. Marksimpson.Com. https://marksimpson.com/meet-themetrosexual/

Symmons-Symonolewicz, K., Thomas, W. I., \& Znaniecki, F. (1960). The polish peasant in europe and america. American Slavic and East European Review, 19(1), 128. https://doi.org/10.2307/3000895 
Wang, S. W., Kao, G. H.-Y., \& Ngamsiriudom, W. (2017).

Consumers' attitude of endorser credibility, brand and intention with respect to celebrity endorsement of the airline sector. Journal of Air Transport Management, 6o, 10-17. https://doi.org/10.1016/j.jairtraman. 2016.12.007

Wells, W. D., Moriarty, S., \& Burnett, J. (2006). Advertising: Principles and practice (7th ed.). Prentice-Hall Inc.

Wen, C., Tan, B. C. Y., \& Chang, K. .-. T. (2009). Advertising effectiveness on social network sites: An investigation of tie strength, endorser expertise and product type on consumer purchase intention. 